\title{
Signs of Change Within the Animal Rights Movement: Results From a Follow-Up Survey of Activists
}

\author{
S. Plous \\ Wesleyan University
}

\begin{abstract}
In 1990, an attitude survey was conducted of 402 animal rights activists attending a national march in Washington, DC (S. Plous, 1991). The present article reports the results of a follow-up survey of 372 activists attending a similar event in 1996. A comparison of the 1990 and 1996 surveys suggests that during this time a significant shift took place in the priorities of the animal rights movement. Whereas a majority of activists in 1990 saw animal research as the most important issue facing the movement, activists in 1996 tended to identify animal agriculture as the most important issue. The 1996 survey also found a modest decline in support for laboratory break-ins, and it found majority support for a 10-point proposal to reduce tensions between activists and researchers. Although these results are subject to certain limitations, they suggest that there may be more room for dialogue between activists and researchers than previously assumed.
\end{abstract}

\begin{abstract}
For all its growing resources and considerable energy, the [animal rights] movement is barely scratching the surface of animal suffering.... Looking at the universe of animal suffering in America today, we see pain dominated by the more than eight billion farm animals, who suffer roughly $95 \%$ of all animal misery.... Let's get out of the past and quit ignoring the vast majority of animal suffering.

-Henry Spira, Coordinator of Animal Rights International
\end{abstract}

These words, penned by one of America's leading animal rights activists (Spira, 1996), raise some intriguing questions: Is the animal rights movement shifting away from its historical focus on animal research? Do most animal rights activists agree that animal agriculture is responsible for the majority of animal suffering? And if so, do they share Spira's view that the animal rights movement is misdirecting its efforts by "ignoring the vast majority of animal suffering"?

Seven years ago, Nicoll and Russell (1990) contentanalyzed several thousand pages of animal rights literature, and they found that of the pages expressing concern about animal use, nearly two thirds focused on animals in research and teaching. After adjusting for the fact that $96.5 \%$ of the animals consumed in the United States are used for food-in contrast to $0.3 \%$ for animal research-Nicoll and Russell calculated that the animal rights "concern-to-use ratio" was 659 times higher for animal research than animal agriculture. That is, on a per-animal basis, the animal rights movement published 659 pages discussing animal research for each page discussing animal agriculture.

A similar emphasis on animal research was found in an

I wish to thank Diane Ersepke for her valuable advice on all phases of this project. For assistance in administering the survey, I also am indebted to Denise Woods, Karen Kurowski, Mark Kurowski, Danielle Bays, Liz Clancy, Linda Huebner, Dena Jones, and Paul Petersan.

Correspondence concerning this article should be addressed to $S$. Plous, Department of Psychology, Wesleyan University, 207 High Street, Middletown, Connecticut 06459-0408. Electronic mail may be sent to splous@wesleyan.edu. attitude survey of animal rights activists conducted during the 1990 "March for Animals" in Washington, DC (Plous, 1991). In this survey, more than 400 activists were asked to identify which issue the animal rights movement should focus on most. The majority answer, given by $54 \%$ of respondents, was "animals used in research." Only $24 \%$ of respondents identified animal agriculture as the most important issue-a result consistent with the findings obtained by Nicoll and Russell (1990).

Thus, it seems that as recently as 1990 , the foremost concern of the animal rights movement was animal research. This emphasis is not surprising given the historical connection between the modern animal rights movement and earlier antivivisectionist movements in England and the United States (Jasper \& Nelkin, 1992; Rowan \& Loew, 1995). Moreover, during the past few decades the animal rights movement has been fueled in large part by a number of well-publicized protests concerning animal research, including cat research at the American Museum of Natural History, primate deafferentation experiments by Edward Taub, and head injury research on baboons at the University of Pennsylvania. No comparable event has ignited concern over farm animal welfare.

One of the central questions explored in the present study is whether the animal rights movement has, for the first time, begun to shift its focus from animal research to animal agriculture. To examine this question, the study took advantage of a natural opportunity for following up the attitude survey mentioned earlier. In 1996, a "March for the Animals" was held in the same location as the 1990 "March for Animals," occurring at roughly the same time of day and during the same time of year (mid-June). As with the 1990 march, the event was sponsored by a coalition of animal rights organizations, and it drew thousands of animal rights activists from around the country (Lipton, 1996). In the study reported in this article, several hundred of these activists completed a survey parallel to the one used in 1990, 
thereby facilitating attitudinal and demographic comparisons across time.

In addition to providing trend information on the priorities and attitudes of animal rights activists, a second purpose of the survey was to assess the degree of activist support for a "peace plan" aimed at deescalating tensions between the animal rights movement and the animal research community. The essential elements of this plan, proposed in May of 1996 by a leading animal protectionist (Clifton, 1996), are outlined in Table 1. Survey respondents were asked to indicate their general level of support or opposition to the plan, and their responses were analyzed in an effort to identify pockets of resistance and support within the animal rights movement. Given the heterogeneity of attitudes and lifestyles found in earlier studies of animal rights activists (Herzog, 1993; Plous, 1991), it was anticipated that activists

Table 1

Summary of Clifton's Proposal to Reduce Conflict Between Animal Rights Activists and Animal Researchers

\begin{tabular}{|c|c|c|}
\hline & $\begin{array}{c}\text { If animal researchers } \\
\text { will ... }\end{array}$ & $\begin{array}{l}\text { Then animal rights } \\
\text { activists will } \ldots\end{array}$ \\
\hline & $\begin{array}{l}\text { Stop trying to portray } \\
\text { animal rights activists as } \\
\text { terrorists }\end{array}$ & $\begin{array}{l}\text { Condemn all violent forms of } \\
\text { activism, including arson, } \\
\text { break-ins, vandalism, and } \\
\text { bomb threats }\end{array}$ \\
\hline 2. & $\begin{array}{l}\text { Open all animal care and } \\
\text { research committee } \\
\text { meetings to the public }\end{array}$ & $\begin{array}{l}\text { Agree not to disrupt animal } \\
\text { care and research meetings } \\
\text { or harass any of the partici- } \\
\text { pants }\end{array}$ \\
\hline 3. 1 & $\begin{array}{l}\text { Hold regular open houses } \\
\text { at laboratories and } \\
\text { address any problems } \\
\text { that the public detects }\end{array}$ & $\begin{array}{l}\text { Stop using exaggerated or } \\
\text { outdated photographs from } \\
\text { animal research that is no } \\
\text { longer conducted }\end{array}$ \\
\hline 4. & $\begin{array}{l}\text { Show a willingness to } \\
\text { police themselves and } \\
\text { discipline researchers } \\
\text { who are abusive to ani- } \\
\text { mals }\end{array}$ & $\begin{array}{l}\text { Discuss suspected animal } \\
\text { abuses with the institution } \\
\text { in question, before going } \\
\text { to the media }\end{array}$ \\
\hline 5. & $\begin{array}{l}\text { Report the number of } \\
\text { rats, mice, and birds used } \\
\text { in research, even if tallies } \\
\text { are not required by law }\end{array}$ & $\begin{array}{l}\text { Stop using old or inflated } \\
\text { estimates of how many } \\
\text { animals are used in } \\
\text { research }\end{array}$ \\
\hline & $\begin{array}{l}\text { Refrain from forming } \\
\text { political alliances with } \\
\text { groups that favor animal } \\
\text { use (e.g., hunters) }\end{array}$ & $\begin{array}{l}\text { Refrain from forming } \\
\text { political alliances with } \\
\text { groups that are anti-science }\end{array}$ \\
\hline & $\begin{array}{l}\text { Recognize the value of } \\
\text { animal protection groups } \\
\text { that are willing to work } \\
\text { cooperatively }\end{array}$ & $\begin{array}{l}\text { Recognize the value of } \\
\text { animal research groups } \\
\text { that are willing to work } \\
\text { cooperatively }\end{array}$ \\
\hline & $\begin{array}{l}\text { End animal dissection in } \\
\text { classes below the upper } \\
\text { division university level }\end{array}$ & $\begin{array}{l}\text { Stop using the dissection } \\
\text { issue to generate opposi- } \\
\text { tion to animal research }\end{array}$ \\
\hline & $\begin{array}{l}\text { Quit buying animals } \\
\text { from random source } \\
\text { dealers (i.e., animals not } \\
\text { bred for research) }\end{array}$ & $\begin{array}{l}\text { Quit claiming that biomedical } \\
\text { researchers are responsible } \\
\text { for families losing their } \\
\text { pets }\end{array}$ \\
\hline 10. & $\begin{array}{l}\text { Acknowledge criticism } \\
\text { respectfully, recognizing } \\
\text { that activists and } \\
\text { researchers share } \\
\text { common ground }\end{array}$ & $\begin{array}{l}\text { Express criticism respect- } \\
\text { fully, recognizing that } \\
\text { activists and researchers } \\
\text { share common ground }\end{array}$ \\
\hline
\end{tabular}

in the present study would show a wide range of reactions to the peace proposal.

\section{Method}

\section{Survey}

In most respects, the 1996 survey was identical in wording and format to the 1990 survey. Respondents were told that the survey was "designed to explore attitudes relating to animals and animal rights" and that the survey was completely anonymous. They were then asked several questions about animal rights, animal research, the animal rights movement, and animal suffering, as well as questions about their personal background and lifestyle (e.g., age, diet, involvement in the animal rights movement). On the concluding page of the survey, respondents were presented with the 10-point plan outlined in Table 1. The plan was identified as having come from "a leading animal rights activist," and respondents were asked, "In general, what is your opinion of this proposal?" (with a 5-point labeled response scale ranging from strongly support to strongly oppose).

\section{Procedure}

Care was taken to follow the same survey administration procedures that were used in 1990 . Members of the research team were deployed along the perimeter of the rally site-located adjacent to the Ellipse in Washington, DC-and respondents were approached as they walked toward the rally (to avoid any biasing effects of the speeches or rally atmosphere). In an effort to reduce respondent selection biases, the research team used a specific approach rule targeting the "next person who walks within 10 feet."

\section{Respondents}

A total of 750 individuals were approached, 614 of whom completed the survey (for an overall compliance rate of $82 \%$ ). Of these 614 respondents, 33 were later excluded from analysis because they were under 18 years of age. This left 581 respondents, 372 of whom met the following criteria for being classified as an animal rights activist: (a) they identified themselves as an animal rights activist, (b) they described themselves as a participant in the animal rights movement, (c) they indicated a belief in the philosophy of animal rights, and (d) they reported traveling from another state expressly to join the march. As discussed in the earlier study (Plous, 1991), the reason for using such a restrictive definition was to identify a highly committed core of activists from around the country.

\section{Results}

In most respects, the demographic profile of respondents in 1996 closely resembled the profile of respondents in 1990 (see Table 2). Nearly all activists were White, and more than three quarters were female. The median age of respondents was 38.0, and the median number of years in the animal rights movement was 8.0 , both slightly higher than the corresponding figures of 33.0 and 5.0 in 1990 (which is as one would expect, given the continuing involvement of activists from 1990). Although the 1990 survey did not measure educational background, the 1996 sample displayed the same high level of educational attainment found in other 
surveys (Jamison \& Lunch, 1992; Richards \& Krannich, 1991). Finally, the 1996 sample closely matched the 1990 sample in geographic dispersion, with respondents living in 40 different states, Canada, Japan, South America, and elsewhere. Thus, the sampling procedure appears to have succeeded in generating a diverse group of committed activists.

There was, however, one notable difference in background between the 1990 and 1996 activists. In 1996, 36\% of activists maintained a vegan diet (i.e., a diet completely devoid of animal products) and only $2 \%$ identified themselves as nonvegetarian, compared with figures of $18 \%$ and $9 \%$, respectively, in 1990 (see Table 2). This shift away from an animal-based diet was highly significant, $\chi^{2}(3, N=764)=$ $41.25, p<.001$, and is consistent with an increase in activist concern about animal agriculture between 1990 and 1996. Also, a modest reduction was found in the percentage of activists who reported buying leather products (from $39 \%$ in 1990 to $34 \%$ in 1996), but this difference was not statistically significant, $\chi^{2}(1, N=762)=1.72$, ns.

\section{Attitudes}

An analysis of the attitude data showed a pronounced shift in the priorities of the animal rights movement (see Table 3). The proportion of activists who felt that animal agriculture should be the top priority of the animal rights movement doubled from $24 \%$ in 1990 to $48 \%$ in 1996 . Conversely, the percentage who saw animal research as the most important issue fell from 54\% in 1990 to $38 \%$ in 1996. This shift in priorities was highly significant, $\chi^{2}(5, N=764)=41.25$, $p<.001$.

In an effort to assess whether activists viewed animal agriculture as responsible for the majority of animal suffering, respondents in the 1996 survey were asked which type

Table 2

Comparison of 1990 and 1996 Respondent Profiles

\begin{tabular}{lll}
\hline & \multicolumn{2}{c}{ Year of survey } \\
\cline { 2 - 3 } Respondent characteristic & 1990 & 1996 \\
\hline Gender (\% female) & 80 & 76 \\
Median age (years) & 33.0 & 38.0 \\
Race (\% White) & near 100 & 96 \\
Highest education completed & & \\
$\quad$ (\%) & - & 1 \\
Grade school & - & 30 \\
High school & - & 41 \\
College & - & 28 \\
Graduate school & & \\
Percentage reporting diet that is & 9 & 2 \\
Nonvegetarian & 28 & 27 \\
Semivegetarian & 45 & 35 \\
Vegetarian & 18 & 36 \\
$\quad$ Vegan & 39 & 34 \\
Percentage who buy leather & & \\
Median years in animal rights & 5.0 & 8.0 \\
$\quad$ movement & & \\
\hline
\end{tabular}

Note. Dashes indicate information that was not requested on the 1990 survey.
Table 3

What Should the Animal Rights Movement Focus on Most?

\begin{tabular}{lcc}
\hline & \multicolumn{2}{c}{ Year of survey } \\
\cline { 2 - 3 } \multicolumn{1}{c}{ Issue } & 1990 & 1996 \\
& $(N=346)$ & $(N=327)$ \\
\hline Animals used in research & 54 & 38 \\
Animals used for food & 24 & 48 \\
Animals used for clothing & 12 & 5 \\
$\quad$ or fashion & 5 & 3 \\
Animals in the wild & & \\
Animals used in sports or & 4 & 5 \\
entertainment & 1 & 2 \\
\hline Animals used in education & & \\
\hline
\end{tabular}

Note. Figures indicate the percentage of respondents giving each answer.

of animal use inflicts the largest amount of suffering each year: hunting, trapping, dissection, animal research, animal agriculture, or "other" (with a blank for respondents to write in their own answer). ${ }^{1}$ In response, $60 \%$ of activists indicated that animal agriculture caused the greatest suffering, $34 \%$ chose animal research, 3\% selected hunting, and 3\% chose one of the three remaining response categories. These results suggest that a majority of activists agree with Spira (1996) that animal agriculture is responsible for the greatest amount of animal suffering.

At the same time, this general finding obscures an important internal division within the animal rights movement. Whereas nearly all activists with an agriculture focus felt that animal agriculture was responsible for the most animal suffering, a majority of activists with a research focus felt that animal research caused the largest amount of suffering (see Table 4). Furthermore, activists whose top priority was animal agriculture differed in other key respects from activists whose top priority was animal research. Relatively speaking, activists with an agriculture focus were more likely to be male, to be under 40 years old, to avoid an animal-based diet and leather products, and to see animal researchers as caring about laboratory animals. Thus, the animal rights movement now appears to include two major subgroups, overlapping yet distinct: a large contingent of young activists who avoid animal products and feel that the movement should focus on animal agriculture, and a smaller contingent of older activists who feel that animal research causes the most suffering and should remain the top priority of the movement. These two groups did not differ significantly in education level, race, or number of years in the animal rights movement.

The emergence of animal agriculture as a top priority of the animal rights movement naturally raises the question of whether there has been a concomitant decline in opposition to animal research, and here the results are quite clear: There

\footnotetext{
${ }^{1}$ This question was placed later in the survey than the item concerning priorities in the animal rights movement. Consequently, the observed change in priorities between 1990 and 1996 cannot be attributed to having asked a question on animal suffering in the 1996 survey.
} 
Table 4

Comparison of Activists Whose Top Priority Is Animal Agriculture With Activists Whose Top Priority Is Animal Research

\begin{tabular}{|c|c|c|c|}
\hline \multirow[b]{2}{*}{$\begin{array}{l}\text { Respondent } \\
\text { characteristic }\end{array}$} & \multicolumn{2}{|c|}{ Top priority } & \multirow[b]{2}{*}{$\begin{array}{c}p \\
\text { value }\end{array}$} \\
\hline & $\begin{array}{l}\text { Animal } \\
\text { agriculture }\end{array}$ & $\begin{array}{l}\text { Animal } \\
\text { research }\end{array}$ & \\
\hline Sex & & & .005 \\
\hline Female & 69 & 84 & \\
\hline Male & 31 & 16 & \\
\hline Age & & & .009 \\
\hline $18-40$ years & 61 & 46 & \\
\hline Over 40 years & 39 & 54 & \\
\hline Maintain diet that is & & & .001 \\
\hline $\begin{array}{c}\text { Nonvegetarian/ } \\
\text { semivegetarian }\end{array}$ & 12 & 46 & \\
\hline Vegetarian & 35 & 31 & \\
\hline Vegan & 53 & 23 & \\
\hline Leather products & & & .001 \\
\hline Buy & 19 & 47 & \\
\hline Do not buy & 81 & 53 & \\
\hline $\begin{array}{l}\text { Believe that the typical } \\
\text { animal researcher }\end{array}$ & & & .045 \\
\hline $\begin{array}{l}\text { Does not care about } \\
\text { animals }\end{array}$ & 75 & 85 & \\
\hline Cares about animals & 17 & 7 & \\
\hline Not sure & 8 & 7 & \\
\hline $\begin{array}{l}\text { Believe most suffering } \\
\text { is caused by }\end{array}$ & & & .001 \\
\hline Animal agriculture & 87 & 27 & \\
\hline Animal research & 8 & 63 & \\
\hline Other & 5 & 10 & \\
\hline
\end{tabular}

Note. Columns 2-3 contain the percentage of respondents giving each answer, and Column 4 contains $p$ values from chi-square tests for independence.

has been no such decline. As shown in Table $5,90 \%$ of activists said that if it were up to them, they would eliminate all research using animals (a small but significant increase over the level of opposition recorded in 1990). In addition, $76 \%$ of activists indicated that their image of a typical animal researcher was someone who "doesn't care about laboratory animals; views animals as expendable supplies," compared with only $15 \%$ who believed that the typical researcher "cares about laboratory animals but feels that research is needed" (the remaining 9\% were not sure). This pattern of responses is not significantly different from the negative view of animal researchers found in 1990, when the percentages were $81 \%, 12 \%$, and $7 \%$, respectively. Indeed, when activists were asked which type of research-medical or psychological-behavioral-yields the most useful information, the majority of respondents said that neither one yields useful information (63\% gave this answer in 1996, compared with $62 \%$ in 1990). On the whole, then, animal rights activists in 1996 showed roughly the same level of opposition to animal research as did activists in 1990.

If there were changes between 1990 and 1996 in attitudes toward animal research, they came not in the degree of opposition but in the type of animal research targeted for elimination and in attitudes toward laboratory break-ins.
When activists were asked in 1990 to indicate which type of research they would most like to eliminate, a plurality of respondents chose psychological-behavioral research over medical research (see Table 5). By 1996, however, this preference had fully reversed, with respondents targeting medical research nearly twice as often as psychologicalbehavioral research. Although the reasons for this reversal are unclear, one possibility may have to do with changing views about the amount of animal suffering caused by each

Table 5

Comparison of 1990 and 1996 Activist Attitudes

Toward Animal Research

\begin{tabular}{|c|c|c|c|}
\hline \multirow[b]{2}{*}{ Survey item } & \multicolumn{2}{|c|}{ Year of survey } & \multirow{2}{*}{$\begin{array}{c}p \\
\text { value }\end{array}$} \\
\hline & 1990 & 1996 & \\
\hline $\begin{array}{l}\text { Would like all animal } \\
\text { research elimi- } \\
\text { nated }\end{array}$ & 85 & 90 & .027 \\
\hline $\begin{array}{l}\text { Image of typical } \\
\text { animal researcher }\end{array}$ & & & .169 \\
\hline $\begin{array}{l}\text { Does not care about } \\
\text { animals } \\
\text { Cares about animals } \\
\text { Not sure }\end{array}$ & $\begin{array}{r}81 \\
12 \\
7\end{array}$ & $\begin{array}{r}76 \\
15 \\
9\end{array}$ & \\
\hline $\begin{array}{l}\text { Which research yields } \\
\text { more useful infor- } \\
\text { mation? }\end{array}$ & & & .180 \\
\hline Medical & 24 & 18 & \\
\hline $\begin{array}{l}\text { Psychological/ } \\
\text { behavioral }\end{array}$ & 2 & 2 & \\
\hline $\begin{array}{l}\text { Yield equally useful } \\
\text { information }\end{array}$ & 2 & 2 & \\
\hline $\begin{array}{l}\text { Neither yields useful } \\
\text { information } \\
\text { Not sure }\end{array}$ & $\begin{array}{l}62 \\
11\end{array}$ & $\begin{array}{l}63 \\
16\end{array}$ & \\
\hline $\begin{array}{l}\text { Which research causes } \\
\text { more animal } \\
\text { suffering? }\end{array}$ & & & $.001^{\mathrm{a}}$ \\
\hline Medical & 13 & 20 & \\
\hline $\begin{array}{l}\text { Psychological/ } \\
\text { behavioral }\end{array}$ & 16 & 9 & \\
\hline $\begin{array}{l}\text { Cause equal amount } \\
\text { of animal } \\
\text { suffering }\end{array}$ & 68 & 62 & \\
\hline $\begin{array}{l}\text { Neither causes } \\
\text { suffering }\end{array}$ & $\begin{array}{l}0 \\
3\end{array}$ & $\begin{array}{l}0 \\
8\end{array}$ & \\
\hline $\begin{array}{l}\text { Which research would } \\
\text { you most like to } \\
\text { eliminate? }\end{array}$ & & 8 & .001 \\
\hline $\begin{array}{l}\text { Medical } \\
\text { Psychological/ }\end{array}$ & 34 & 47 & \\
\hline behavioral & 45 & 27 & \\
\hline $\begin{array}{l}\text { Not sure } \\
\text { Believe laboratory } \\
\text { break-ins are }\end{array}$ & 21 & 26 & 016 \\
\hline $\begin{array}{l}\text { Personally favor labo- } \\
\text { ratory break-ins }\end{array}$ & 61 & 55 & .080 \\
\hline
\end{tabular}

Note. Columns 2-3 contain the percentage of respondents giving each answer, and Column 4 contains $p$ values from chi-square tests for independence.

aTest excluded the "Neither" category because of low expected frequencies. 
type of research. As seen in Table 5, 84\% of activists in 1990 thought that psychological-behavioral research caused at least as much suffering as medical research, whereas only $71 \%$ thought this in 1996.

The other significant change in attitudes toward animal research had to do with one of the most contentious issues dividing the animal rights movement: the issue of break-ins at animal laboratories. Between 1990 and 1996, the percentage of activists who saw break-ins as "an effective way to discourage animal research" fell significantly from a majority view $(56 \%)$ to a minority view $(48 \%)$. Consistent with this decline, the percentage of activists who personally favored break-ins also showed a modest reduction, from $61 \%$ in 1990 to $55 \%$ in 1996 . These trends suggest that a growing number of activists prefer other means of addressing their concern about animal research. In the next section, support for one such approach is examined: the 10-point "peace plan" proposed by Clifton (1996).

\section{Support for the 10-Point Plan}

Despite the fact that $55 \%$ of activists supported laboratory break-ins, slightly more than $50 \%$ also said that they would support the 10-point proposal if animal researchers were to accept the agreement. Specifically, $29 \%$ of activists said they would "strongly support" the plan, $22 \%$ said they would "support" it, $18 \%$ said they would "oppose" the plan, $15 \%$ said they would "strongly oppose" it, and $17 \%$ said they were not sure how they felt about the proposal. Because the 10-point plan requires activists to condemn break-ins, majority support for the plan means that a subset of break-in supporters were willing to renounce this tactic in the interest of compromise. To determine the size of this subset, support for the proposal was broken down by support for laboratory break-ins, and the results showed that $42 \%$ of break-in supporters were willing to condemn break-ins if animal researchers would agree to the proposal (see Table 6).

Additional analyses were conducted to determine whether support for the 10-point plan varied among subgroups of activists. According to these analyses, support for the plan did not depend significantly on activists' gender, age, race, education level, or number of years in the animal rights movement. Nor did support depend on whether activists viewed animal researchers as caring about laboratory animals or whether activists viewed animal research as the single most important issue facing the animal rights movement $(51 \%$ of the latter respondents supported the plan, compared with $50 \%$ of other activists). These results suggest that the proposal was supported even by activists who might have been expected to resist compromise (e.g., highly experienced, research-focused activists with negative views about animal researchers).

Although opposition to the plan did not vary significantly with these factors, it did depend on activists' intensity of commitment and on the absolutism of their convictions. As shown in Table 6, opposition to the compromise was associated with a belief that all animal research should be eliminated, a belief that neither medical nor psychologicalbehavioral research yields useful information, a belief that
Table 6

Activist Attitudes Toward the 10-Point

Plan for Compromise

\begin{tabular}{|c|c|c|c|c|}
\hline \multirow{2}{*}{$\begin{array}{l}\text { Subgroup of } \\
\text { respondents }\end{array}$} & \multicolumn{3}{|c|}{ Attitude toward plan (\%) } & \multirow{2}{*}{$\underset{\text { value }}{p}$} \\
\hline & Support & Oppose & Not sure & \\
\hline Maintain diet that is & & & & .001 \\
\hline $\begin{array}{l}\text { Nonvegetarian/ } \\
\text { semivegetarian }\end{array}$ & 71 & 14 & 16 & \\
\hline Vegetarian & 54 & 29 & 16 & \\
\hline Vegan & 30 & 52 & 18 & \\
\hline Leather products & & & & .001 \\
\hline Buy & 70 & 17 & 13 & \\
\hline Do not buy & 40 & 42 & 18 & \\
\hline $\begin{array}{l}\text { Position on animal } \\
\text { research }\end{array}$ & & & & .001 \\
\hline $\begin{array}{l}\text { Want to eliminate } \\
\text { some }\end{array}$ & 91 & 9 & 0 & \\
\hline $\begin{array}{l}\text { Want to eliminate } \\
\text { all }\end{array}$ & 46 & 35 & 18 & \\
\hline $\begin{array}{l}\text { Perceived usefulness } \\
\text { of medical and } \\
\text { psychological/ } \\
\text { behavioral }\end{array}$ & & & & \\
\hline research & & & & .001 \\
\hline $\begin{array}{l}\text { One or both can } \\
\text { yield useful }\end{array}$ & & & & \\
\hline $\begin{array}{c}\text { information } \\
\text { Neither one yields }\end{array}$ & 67 & 21 & 12 & \\
\hline $\begin{array}{l}\text { useful informa- } \\
\text { tion }\end{array}$ & 41 & 40 & 19 & \\
\hline $\begin{array}{l}\text { Belief concerning } \\
\text { effectiveness of } \\
\text { break-ins }\end{array}$ & & & & .012 \\
\hline $\begin{array}{l}\text { Break-ins are not } \\
\text { effective }\end{array}$ & 62 & 25 & 13 & \\
\hline $\begin{array}{l}\text { Not sure about } \\
\text { effectiveness } \\
\text { Break-ins are }\end{array}$ & 54 & 27 & 19 & \\
\hline effective & 42 & 40 & 18 & \\
\hline $\begin{array}{l}\text { Personal position on } \\
\text { laboratory }\end{array}$ & & & & \\
\hline break-ins & & & & .001 \\
\hline $\begin{array}{l}\text { Do not favor } \\
\text { break-ins }\end{array}$ & 72 & 17 & 11 & \\
\hline $\begin{array}{l}\text { Not sure of posi- } \\
\text { tion }\end{array}$ & 56 & 23 & 21 & \\
\hline Favor break-ins & 42 & 43 & 17 & \\
\hline
\end{tabular}

Note. Columns $2-4$ contain the percentage of respondents supporting, opposing, or not sure about the plan (i.e., each row adds to 100 , aside from rounding errors). Column 5 contains $p$ values from chi-square tests for independence.

laboratory break-ins are effective and should be continued, a refusal to buy products made with leather, and a diet low in animal products. Interestingly, when all of these variables were entered into a stepwise regression analysis, the single best predictor of opposition to the 10-point plan had nothing to do with animal research-it had to do with whether activists maintained a diet low in animal products. Thus, the prospects for compromise over animal research appear to depend more on activists' level of commitment and absolutism than on their views about animal research per se. 


\section{Discussion}

This study constitutes the first large-scale attempt to track changes over time in the animal rights movement. Although the results showed relatively few changes in demographic composition and attitudes between 1990 and 1996, one notable trend stood out: a shift in concern from animal research to animal agriculture. Activists in the latest survey were twice as likely as activists in the former one to maintain a vegan diet, and they were twice as likely to say that the animal rights movement should focus on animal agriculture as the issue of highest priority. If this shift is corroborated by other investigations, it means that an unprecedented change has taken place within the animal rights movement-a change in which animal agriculture has replaced animal research as the top-priority issue.

The modern animal rights movement can be traced to two earlier movements in Victorian England: the anticruelty "humane movement" of the early 19th century and the more radical "antivivisection movement" of the late 19th century (Dewsbury, 1990; Jasper \& Nelkin, 1992). For more than a century these two movements have coexisted as uneasy allies in animal protection, and it may therefore be tempting to view the current results as an ascendance of humane activism over antivivisectionism. Yet such an interpretation would be mistaken on two counts. First, activists in the 1996 survey showed the same level of support for antivivisectionism that was found in 1990 (roughly $90 \%$ favored the elimination of animal research, regardless of whether their top priority was animal research or animal agriculture). Second, humane activism - whether in the anticruelty movement of Victorian England or the animal welfare movement of the United States-has never focused centrally on animal agriculture or the promotion of a vegetarian diet. These facts leave little doubt, then, that the current results do not represent a cyclical alternation between antivivisectionism and humane activism. Rather, they signal a new chapter in the animal rights movement.

Of course, as with any initial study, the present research was limited in certain respects, and these limitations should temper any conclusions that are drawn. Perhaps the most obvious of these limitations is that respondents were not sampled randomly from the full universe of animal rights activists. Activists traveling to attend a national march may differ importantly from other activists, and it remains a task for future research to determine how generalizable the present results are.

It should also be noted that the ideal research design for studying attitude change is usually a longitudinal design in which the same respondents are measured over repeated occasions. Instead, the current study used the same type of cross-sectional design employed in opinion polls (i.e., it drew two different samples using the same sampling procedure). Although there are several advantages to such a design, one important disadvantage is that any changes observed over time may be confounded with other factors. For example, because the 1990 event was attended by approximately eight times more activists than the 1996 event (Herzog, 1996), it is possible that the two surveys sampled from underlying populations that differed in their commitment to animal rights activism.

While this concern should not be dismissed lightly, there is at least some evidence that the two surveys did succeed in tapping into the same general population of activists. First, in most respects the activist profiles in 1990 and 1996 were remarkably similar to each other. Except for the items on diet and animal agriculture, most survey questions yielded marginal differences of less than $10 \%$ between 1990 and 1996. Second, event organizers used similar methods of activist recruitment for both national marches. Mailings and advertisements promised an animal rights event of "historic" proportions, and no special emphasis was given to specific issues such as animal agriculture or animal research. Hence, it is unlikely that the two marches drew from substantially different animal rights constituencies.

Beyond assessing changes over time, an additional purpose of the present study was to explore the possibility of reducing tensions between animal rights activists and animal researchers. In recent years, a number of authors have suggested that there is room for compromise in the animal research debate (Bowd, 1990; Paul, 1995; Varner, 1994), and results from the current study support this assertion. When activists were presented with a 10-point plan for compromise, a narrow majority indicated that they would support the proposal (compared with fewer than one activist in three who said they would oppose the plan). Moreover, given the fact that respondents in the current study were highly committed activists, the observed level of support probably constitutes a conservative estimate of how willing most animal rights advocates are to compromise. Although the difficulty of reaching any such compromise should not be underestimated, these findings suggest that there may be more room for dialogue than previously assumed.

In light of these results, the next logical step is to assess the readiness of animal researchers to support a plan for compromise. As Clifton (1996) noted, many of the points in his proposal are based on trends already taking place (e.g., open houses at laboratories, discontinuation of dissection in introductory classes). Nonetheless, systematic research should assess whether the prospect of a "cease-fire" is as attractive to animal researchers as it is to animal rights activists. If the results are positive, it may then be possible to negotiate an agreement between major animal rights groups and animal research organizations, thereby facilitating a mutually beneficial process of constructive dialogue.

\section{References}

Bowd, A. D. (1990). A decade of debate on animal research in psychology: Room for consensus? Canadian Psychology, 31, 74-82.

Clifton, M. (1996, May). Peace talk. Animal People, p. 2.

Dewsbury, D. A. (1990). Early interactions between animal psychologists and animal activists and the founding of the APA Committee on Precautions in Animal Experimentation. American Psychologist, 45, 315-327.

Herzog, H. A., Jr. (1993). "The movement is my life": The psychology of animal rights activism. Journal of Social Issues, 49, 103-119. 
Herzog, H. A., Jr. (1996). A test of the declining interest hypothesis. American Psychologist, 5I, 1184.

Jamison, W., \& Lunch, W. (1992). Rights of animals, perceptions of science, and political activism: Profile of American animal rights activists. Science, Technology and Humane Values, 17 , 438-458.

Jasper, J. M., \& Nelkin, D. (1992). The animal rights crusade: The growth of a moral protest. New York: Free Press.

Lipton, E. (1996, June 24). Adamant about animal rights. The Washington Post, p. B3.

Nicoll, C. \$., \& Russell, S. M. (1990). Analysis of animal rights literature reveals the underlying motives of the movement: Ammunition for counter offensive by scientists. Endocrinology, I27, 985-989.

Paul, E. S. (1995). Us and them: Scientists' and animal rights campaigners' views of the animal experimentation debate. Society and Animals, 3, 1-21

Plous, S. (1991). An attitude survey of animal rights activists. Psychological Science, 2, 194-196.
Richards, R. T., \& Krannich, R. S. (1991). The ideology of the animal rights movement and activists' attitudes toward wildlife. In R. E. McCabe (Ed.), Transacrions of the 56th North American Wildlife and Natural Resources Conference (pp. 363-371). Washington, DC: Wildlife Management Institute.

Rowan, A. N., \& Loew, F. M. (1995). The animal nesearch controversy: Prorest, process \& public policy. North Grafton, MA: Tufts University, Center for Animals \& Public Policy.

Spira, H. (1996, June). HyperActivism: The phenomenon of doing without achieving. Animal People, p. 5.

Vamer, G. E. (1994, January-February). The prospects for consensus and convergence in the animal rights debate. Hartings Center Report, 24, 24-28.

Received January 21, 1997

Revision received May 21, 1997

Accepted May 22, 1997 